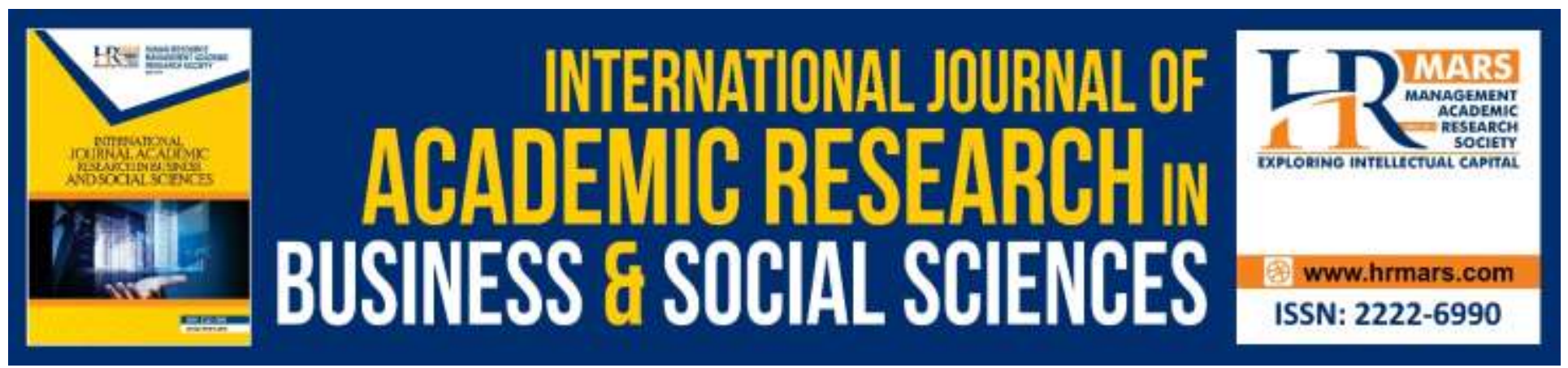

\title{
The Impact of Dimensions of Social Responsibility on Organizational Commitment an Empirical Study in Telecommunication Sector in Syria
}

\author{
Hassan Ismail, Lubaba Sukkar
}

To Link this Article: http://dx.doi.org/10.6007/IJARBSS/v10-i1/6818

DOI:10.6007/IJARBSS/v10-i1/6818

Received: 05 December 2019, Revised: 20 December 2019, Accepted: 16 January 2020

Published Online: 30 January 2020

In-Text Citation: (Ismail \& Sukkar, 2020)

To Cite this Article: Ismail, H., \& Sukkar, L. (2020). The Impact of Dimensions of Social Responsibility on Organizational Commitment an Empirical Study in Telecommunication Sector in Syria. International Journal of Academic Research in Business and Social Sciences, 10(1), 126-143.

Copyright: (c) 2020 The Author(s)

Published by Human Resource Management Academic Research Society (www.hrmars.com)

This article is published under the Creative Commons Attribution (CC BY 4.0) license. Anyone may reproduce, distribute, translate and create derivative works of this article (for both commercial and non-commercial purposes), subject to full attribution to the original publication and authors. The full terms of this license may be seen

at: http://creativecommons.org/licences/by/4.0/legalcode

\section{Vol. 10, No. 1, 2020, Pg. 126 - 143}

Full Terms \& Conditions of access and use can be found at http://hrmars.com/index.php/pages/detail/publication-ethics 


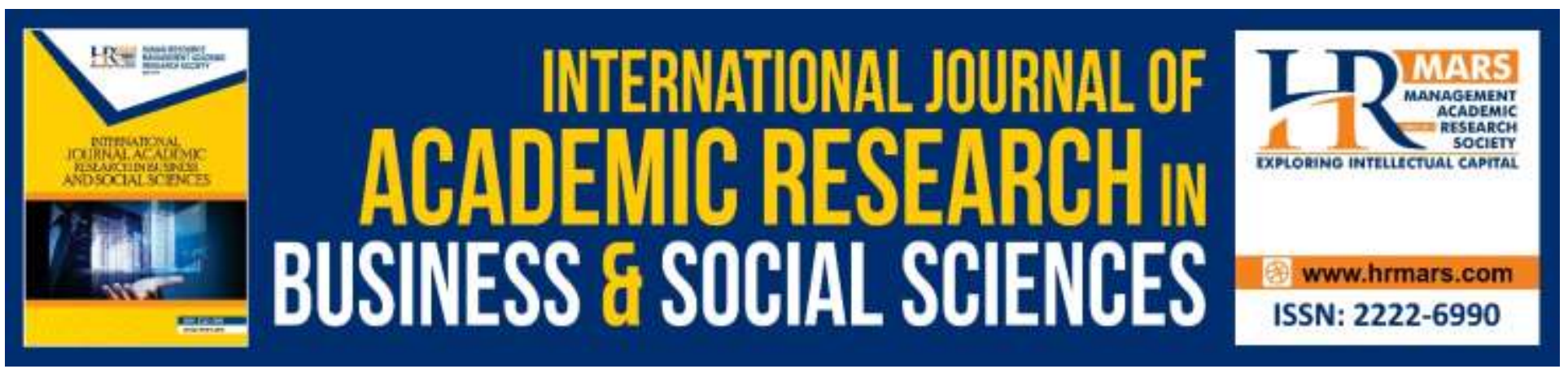

\title{
The Impact of Dimensions of Social Responsibility on Organizational Commitment an Empirical Study in Telecommunication Sector in Syria
}

\author{
Hassan Ismail \\ Department of Human Resources management, Higher Institute of Business Administration (HIBA) \\ Damascus, Syria \\ Email: Hassanisml@gmail.com \\ Lubaba Sukkar \\ Researcher, Department of Human Resource Management, Higher Institute of Business \\ Administration (HIBA), Damascus, Syria \\ Email: lubabasukkar@yahoo.com
}

\begin{abstract}
This study aimed to discover the impact of applying the social responsibility dimensions on workers in organizational commitment and the intermediate role of work meaning. The research community is represented in the telecommunications sector in Damascus. To achieve the objectives of the research, the descriptive analytical approach was adopted. Secondary data were collected from previous studies and relevant references, while the questionnaire was the main research tool for primary data collection. The questionnaire data were analyzed using a linear regression method and comparing averages

The researcher reached a set of results including:

1-There is a significant significance of the dimensions of social responsibility (social responsibility towards society - social responsibility towards employees - social responsibility towards customers) in the emotional commitment of employees in the telecommunications sector in Damascus.

2-There is a significant impact of the social responsibility dimensions (social responsibility towards the community and social responsibility towards the employees) in the continuous commitment of employees in the telecommunications sector in Damascus.

3- There is a significant significance of the dimensions of social responsibility (social responsibility towards society - social responsibility towards workers) in the standard commitment of employees in the telecommunications sector in Damascus.
\end{abstract}

Keywords: Corporate Social Responsibility (Csr), Organizational Commitment. 


\section{Introduction}

During the past decade, firms have come under increasing pressure to pursue socially responsive behavior from a variety of stakeholder groups including shareholders, employees, investors, consumers, and managers (Kapstein, 2001; Berman, Wicks, Kotha, and Jones, 1999; Donaldson and Preston, 1995). As the threats and opportunities associated with corporate social and environmental responsibilities have become better understood, companies have sought to generate strategic capital from the acceptance of these responsibilities. In light of this, significant strands of research have investigated whether there are financial payoffs to increased social responsiveness (Griffin and Mahon, 1997; Waddock and Graves, 1994; McWilliams and Siegel, 2001; Orlitzky, Schmidt, and Rynes, 2003), the influence of perceptions concerning corporate social responsiveness on customers (Romm, 1994; Solomon and Hanson, 1985; McGuire, Sundgren and Schneeweis, 1988; Smith, 1994; Jones, 1997), and the attractiveness of social performance to investors (Graves and Waddock, 1994; Coffey and Fryxell, 1991; Johnson and Greening, 1999).

Considerable attention has also been paid to the importance of employees in corporate social responsiveness (Turban and Greening, 1996; Greening and Turban, 2000; Albinger and Freeman, 2000; Backhaus, Stone and Heiner, 2002; Peterson, 2004). These studies provide evidence of payoffs to improved social responsibility, including the observation that more socially responsible corporations are more attractive to potential employees and that they may therefore benefit from larger applicant pools (Turban and Greening, 1996; Greening and Turban, 2000), and a more committed workforce because "employees will be proud to identify with work organizations that have favorable reputation" (Peterson, 2004, p, 299).

Indeed, a recent survey found that $58 \%$ of UK employees believed that the social and environmental responsibilities of the organization they worked for are very important (Dawkins, 2004), with other evidence highlighting that corporate social and environmental values may play a particularly significant role in the recruitment of new graduates (Scott, 2004).

\section{Literature Review and Hypothesis Development What Is CSR?}

The International Organization for Standardization, known as ISO, strategic advisory group on CSR describes it as "a balanced approach for organizations to address economic, social and environmental issues in a way that aims to benefit people, communities and society." 1 CSR includes consideration of such issues as:

- Human rights.

-Workplace and employee issues, including occupational health and safety.

- Unfair business practices.

- Organizational governance.

- Environmental aspects.

- Marketplace and consumer issues.

- Community involvement.

- Social development. 
Ethics and values are essentials on which businesses are founded and through which success can be achieved and communities developed. CSR has always been a major influence in the business world and is growing in importance as it is increasingly supported by business models and standards. In the aftermath of the scandals, the public, which includes our customers, is asking whether The business community can be trusted. Business-Week said companies are "scrambling aboard there form bandwagon. Throughout corporate America, companies are adding more outsiders to boards, beefing up crucial committees and recruiting financial experts to bolster their audit panels.

"2The need for reform was highlighted at the Malcolm Baldrige National Quality Award 2001ceremony on March 7, 2002, when President Bush called for a "renewed sense of corporate responsibility. "He went on to state, "The whole design of free market capitalism depends on free people acting responsibly. ... Managers should respect workers.

A firm should be loyal to the community, mindful of the environment.

"3As for the acceptance of CSR as a critical business issue, a KPMG CSR based survey released on June 10,2002 , reported, "While the message is still working its way across corporate America, companies that embrace this approach are finding it is just good business sense, that they are rewarded with an enhanced reputation that often leads to greater financial value for the enterprise.

\section{Definition of Corporate Social Responsibility}

According to Howard R. Bowen in his book: "Social Responsibility of the Businessman"(1953) gives the initial definition of CSR as "the obligation of businessmen to pursue those policies, to the make those decision or to follow those which line of action are desirable in terms of the objectives and values of our society".

In 2004, Darwin gave the definition of corporate social responsibility as with a mechanism for a company to voluntarily integrate social environmental concerns into its operations and interactions with stakeholders, social responsibility beyond the law.

A year later, another definition appear on Corporate Social Responsibility (CSR) is a company's commitment to improve the welfare of the community through good business practices and contributes most of company resources (Kotler and Nancy, 2005).

In 2007, Wibisono defines Corporate Social Responsibility (CSR) as a business conducted in a transparent and open and based on moral values and uphold respect for employees, communities and the environment.

Opinions in the Suharto Friedman (2008) states that the primary goal is to gain Profit Corporation simply being abandoned. Instead the concept of the triple bottom line (profit, planet, people) that was initiated by John Elkington increasingly enter into mainstream business ethics (Suharto, 2008) According to Pearce and Robinson (2007) there are ten parties have different interests and different perspectives to the company. Ten parties are referred to stockholders, creditors, employees, customers, suppliers, governments, unions, competitors, local communities and general public. Interests in question could claim economic and noneconomic claims.

Pearce and Robinson (2007) classifies social responsibility into four groups as follows Economist Responsibility corporate responsibility is to produce goods and services to the public at reasonable prices and provide benefits for the company. 
Legal Responsibility wherever the company operates will certainly not be separated from the rules and laws - laws applicable at the site, especially the rules governing business activities. The Regulation 29 primarily related to environmental regulation and consumer protection Ethical Responsibility established company not only comply with and obey the laws, but also should have ethics Discretionary responsibility, voluntary responsibilities such as dealing with people, being good citizens, etc.

Until now there is no universal definition of CSR that is acceptable to all agencies. There are different versions of the definitions of CSR are as follows

World Business Council for Sustainable Development: continuous commitment of the conduct of business to behave ethically and contribute to economic development while improving the quality of life of employees and their families and local communities and the general public.

International Finance Corporation: Commitment world of business to contribute to sustainable economic development by working with employees, their families, local communities and society at large to improve their lives in a way - a good way for business and development Institute of Chartered Accountants, England and Wales: Assurance that organizes-business management organization capable of providing a positive impact on society and the environment, searaya maximize value for shareholders (shareholder) they Canadian Government: Business activities that integrate economic activity, environmental and social into the values, culture, decision-making, strategy and operations performed seacara transparent and the responsibility to create a healthy and growing community.

European Commission: A concept whereby companies integrate social and environmental attention to their business operations and in their interaction with stakeholders (stakeholders) berdasakan principle of volunteerism CSR Asia: The company's commitment to operate in a sustainable manner based on economic principles, social and economic interests while meyeim bangkan diverse stakeholder.

Study Circle CSR Indonesia: earnest efforts of the business entities to minimize negative impacts and maximize the positive impact of its operations on all stakeholders in the economic, social, and environment in order to achieve the goal of sustainable development.

Furthermore, According to Nor Hadi (2011) CSR can be defined as a form of action that departs from company's ethical consideration which aimed to improving the economy, which is accompanied by improving the quality of life for employees following their families, and simultaneously improved quality of life for local communities and the wider society.

From the various understanding of CSR as diverse can be concluded that CSR is an act of the company's business that are not only aimed at improving the company's financial benefit, but also for socio-economic development of the region as a whole, institutionalized and sustained.

\section{CSR is Variously Defined as}

" The continuing commitment by business to behave ethically and contribute to economic development while improving the quality of life of the workforce and their families as well as of the local community and society at large." (World Business Council for Sustainable Development).

"Being socially responsible means not only fulfilling legal expectations, but also going beyond compliance and investing more into human capital, the environment and relations with stakeholders." (The European Commission). 
"Operating a business in a manner that meets or exceeds the ethical, legal, commercial and public expectations that society has of business."

(Business for Social Responsibility).

Corporate Social Responsibility can best be understood in terms of the changing relationship between business and society. Many people believe it is no longer enough for a company to say that their only concern is to make profits for their shareholders, when they are undertaking operations that can fundamentally affect (both negatively or positively) the lives of communities in countries throughout the world.

Degree of influence From Market actions to Market remolding to Policy influence we rely on definitions that exclude economic and legal components of CSR and adopt a CSR stakeholder framework that classifies CSR actions into four main categories (Turker 2009):

- CSR toward social and nonsocial stakeholders this component represents the responsibility of a business toward society, the natural environment, next generations, and nongovernmental agencies. - CSR toward employees The firm's actions must ensure the well-being and support of its employees, including career opportunities, organizational justice, family friendly policies, safety, job security, and union relations.

- CSR toward customers this dimension relates to the responsibilities of a business toward consumers and products, including product safety, customer care, and handling customer complaints, beyond the law.

- CSR toward government the firm is responsible to comply with the law and governmental rules and pay taxes

The Dimensions of Corporate Social Responsibility It is impossible to draw up a definitive list of issues and policies, which constitute CSR. These will be different for different companies and can shift over time as changes in risk and regulation, challenges to reputation and developments in best practice redefine the boundaries of what is acceptable, possible and profitable for a company to do. Nevertheless it is possible to map out CSR in terms of a number of key interlocking dimensions, which can each range from the most narrow, compliance-based, reactive modes to the broadest, most strategic and potentially most significant in terms of addressing major social and environmental problems. Figure 1 The Dimensions of CSR Focus of accountability From Legal and traditional stakeholders to Direct stakeholders, short-term impacts to Broad range of stakeholders, long-term Impact Business case From Pain alleviation to Cost-benefit rationale to Strategic alignment Level of engagement From Compliance with legal responsibilities to Harm minimization to Social value creation Degree of

\section{Why is Corporate Social Responsibility becoming so important?}

_ Globalization and the associated growth in competition.

_ Increased size and influence of companies.

_ Retrenchment or repositioning of government and its roles.

_ War for talent; companies competing for expertise.

_ Growth of global civil society activism.

_ Increased importance of intangible assets.

Source: Boston College Centre for Corporate 
Community Relations, Making the Business Case:

Determining the Value of Corporate Community

Involvement, 2000

\section{Organizational Commitment}

Organizational commitment is the employees' state of being committed to assist in the achievement of the organization's goals, and involves the employees' levels of identification, involvement, and loyalty (Caught \& Shadur, 2000). It is an emotional response that can be measured through people's behaviors, beliefs, and attitudes and can range anywhere from very low to very high. John Meyer and Nancy Allen (1997) have identified three types of organizational commitment: affective, continuance, and normative.

- Affective or moral commitment occurs when individuals fully embrace the goals and values of the organization. They become emotionally involved with the organization and feel personally responsible for the organization's level of success. These individuals usually demonstrate high levels of performance, positive work attitudes, and a desire to remain with the organization.

- Continuance or calculative commitment occurs when individuals base their relationship with the organization on what they are receiving in return for their efforts and what would be lost if they were to leave (i.e., pay, benefits, associations). These individuals put forth their best effort only when the rewards match their expectations.

- Normative commitment occurs when individuals remain with an organization based on expected standards of behavior or social norms. These individuals value obedience, cautiousness, and formality. Research suggests that they tend to display the same attitudes and behaviors as those who have affective commitment.

Zangaro (2001) suggests that an additional type, alienative commitment, may also exist. He writes that this occurs when individuals feel they have little or no control or impact, and would like to leave their jobs. These employees usually demonstrate low levels of performance.

\section{Overall Analysis of Commitment Construct Definitions}

Meyer and Herscovitch (2001, p. 301) propose that commitment is "a force that binds an individual to a course of action of relevance to one or more targets". Employees are theorized to experience this force in the form of three bases, or mindsets: affective, normative, and continuance, which reflect emotional ties, perceived obligation, and perceived sunk costs in relation to a target, respectively (Allen and Meyer, 1990). Thus,

any scale that purports to measure organizational commitment should tap one of these mindsets and should reference the target, what the employee is committed to, be it the organization, a team, a change initiative, or a goal.

Additionally, Meyer and Herscovitch (2001, p. 311) argue that commitments include 'behavioral terms' that describe what actions a commitment implies. Specifically, these terms can take the form of focal and discretionary behavior. A focal behavior is one believed

to be integral to the concept of commitment to a particular target, such that all three mindsets should predict this behavior. It is the behavior "to which an individual is bound by his or her commitment". 
For example, for organizational commitment, the focal behavior is theorized to be maintaining membership in the organization. In contrast, discretionary

behaviors are 'optional', in the sense that the employee has some flexibility in defining the behavioral terms of his commitment. Some mindsets, but not others, may predict these behaviors. Meyer and Herskovits argue that different behavioral terms should be included in item wording, depending on the kind of behavior the researcher is trying to predict.

Finally, Meyer et al. (2006); Sahid, Noordin, \& Sani (2018): Ejike (2018) note that commitment has both cognitive and affective elements. The cognitive elements are the behavioral terms and the basis of the commitment, and the affective element comprises whatever feelings a specific mindset invokes (e.g., in the case of NC, pride and/or guilt).

\section{Prerequisites for Organizational Commitment}

Regardless of what companies do, some employees display greater organizational commitment than others. Researchers have found that certain characteristics, attitudes, and relationships may play key roles in environments with high levels of organizational commitment.

Personal characteristics are important factors in the development of an individual's level of organizational commitment. Mathieu and Zajac (1990) have identified several personal characteristics:

- Age: Older workers tend to be more committed than younger ones. Some researchers have emphasized negative reasons for this finding: older workers have fewer occupational alternatives and would risk their benefits if they left an organization. Others have focused on findings that older workers have greater job satisfaction and have better jobs.

- Gender: Men tend to be somewhat less committed to organizations than women.

- Education: More highly-educated workers tend to be less committed. One explanation is that they may have greater expectations of the organization which cannot always be met.

- Perceived competence: Employees who perceive themselves as having higher levels of competence tend to display greater organizational commitment. It has been proposed that this occurs because these workers can use the organization to meet their needs for growth and achievement.

- Protestant (or Puritan) work ethic: Employees who believe in the intrinsic value and necessity of work also believe that the organization is the place where their need to do work can be satisfied.

Job attitudes also contribute to an individual's level of organizational commitment.

- Job satisfaction is the only attitude variable studied more than organizational commitment. Job satisfaction is "the degree to which people like their jobs" (Spector, 1997, p.vii) based on "what they receive from working compared to what they expect, want, or think they deserve" (Klinger \& Nalbandian, 1993, p.175).

\section{Research Hypothesis}

Hypothesis

$\mathrm{H} 1$ : There is a significant impact of CSR dimensions on organizational commitment.

It is divided into three hypotheses:

First: There is a significant impact of the dimensions of social responsibility in affective commitment. 
INTERNATIONAL JOURNAL OF ACADEMIC RESEARCH IN BUSINESS AND SOCIAL SCIENCES

Vol. 10, No. 1, Jan, 2020, E-ISSN: 2222-6990 C 2020 HRMARS

Second: There is a significant impact of the dimensions of social responsibility in the normative commitment.

Third: There is a significant impact of the dimensions of social responsibility in the continuous commitment.

\begin{tabular}{|c|c|}
\hline $\begin{array}{r}\text { Dimensions of Social } \\
\text { Responsibility }\end{array}$ & \\
\hline $\begin{array}{l}\text { Social responsibility towards } \\
\text { society }\end{array}$ & Organizational Commitment \\
\hline $\begin{array}{l}\text { Social responsibility towards } \\
\text { customers }\end{array}$ & $\begin{array}{l}\text { affective commitment } \\
\text { normative commitment }\end{array}$ \\
\hline $\begin{array}{l}\text { Social responsibility towards } \\
\text { employees }\end{array}$ & continuous commitment \\
\hline $\begin{array}{l}\text { Social responsibility towards } \\
\text { Governments }\end{array}$ & \\
\hline
\end{tabular}

\section{Research Methodology}

\section{Data Collection and Sample}

Data for this study were collected from both primary and secondary sources. Secondary data were collected through comprehensive literature review. The primary data were collected from workers in the telecommunications sector in Damascus. A total sample of 233 .A questionnaire related to the study's variables was the main tool of this study.

\section{Measurement}

The questionnaire included three sections: dimensions of social responsibility (1. Social responsibility towards society 2 . Social responsibility towards customers 3 . Social responsibility towards employees 4. Social responsibility towards Governments) and organizational commitment (affective commitment,

Normative commitment, continuous commitment) and basic demographic information.

Apart from basic demographic information a 5-point Likert scale format was used, and the scores on the scale ranged from $1=$ Strongly Disagree to $5=$ Strongly Agree.
4.1CSR: is measured using18 items the scale reported reliability0.94\%. 4.2: organizational commitment is measured using 24 items the scale reported reliability $0.85 \%$.

\section{Data Analysis}

This study examines the impact of CSR on OC. Table (1') shows the results of the regression analysis regarding the effect of CSR on affective commitment. As presented in table (1), model is significant at $5 \%$ level $(\mathrm{R} 2=.564)$. Table $(5)$ shows the results of the regression analysis regarding the effect of 
INTERNATIONAL JOURNAL OF ACADEMIC RESEARCH IN BUSINESS AND SOCIAL SCIENCES Vol. 10, No. 1, Jan, 2020, E-ISSN: 2222-6990 @ 2020 HRMARS

CSR on continuous commitment. As presented in table (2), model is significant at $5 \%$ level ( $R 2=.261$ ). Table (6) shows the results of the regression analysis regarding the effect of CSR on normative commitment. As presented in table (3), model is significant at $5 \%$ level ( $R 2=.263$ ).

\begin{tabular}{|c|c|c|c|c|c|}
\hline \multirow[b]{2}{*}{ Model } & \multicolumn{4}{|c|}{ Model Summary } & \multirow[b]{2}{*}{ Durbin-Watson } \\
\hline & $\mathrm{R}$ & R Square & $\begin{array}{c}\text { Adjusted R } \\
\text { Square } \\
\end{array}$ & $\begin{array}{l}\text { Std. Error of the } \\
\text { Estimate }\end{array}$ & \\
\hline 1 & $.751^{\mathrm{a}}$ & .564 & .557 & .42439 & 1.596 \\
\hline
\end{tabular}

a. Predictors: (Constant)social responsibility (social responsibility towards society - social responsibility towards employees - social responsibility towards customers)

b. Dependent Variable: the emotional commitment

\begin{tabular}{|c|c|c|c|c|c|c|c|c|}
\hline \multicolumn{9}{|c|}{ Coefficients ${ }^{a}$} \\
\hline \multirow{2}{*}{\multicolumn{2}{|c|}{ Model }} & \multicolumn{2}{|c|}{$\begin{array}{l}\text { Unstandardized } \\
\text { Coefficients }\end{array}$} & \multirow{3}{*}{$\begin{array}{c}\text { Standardized } \\
\text { Coefficients } \\
\text { Beta } \\
\end{array}$} & \multirow{3}{*}{$\frac{t}{4.539}$} & \multirow{3}{*}{$\begin{array}{l}\text { Sig. } \\
.000\end{array}$} & \multicolumn{2}{|c|}{$\begin{array}{c}\text { Collinearity } \\
\text { Statistics }\end{array}$} \\
\hline & & $\mathrm{B}$ & Std. Error & & & & Tolerance & VIF \\
\hline \multirow[t]{5}{*}{1} & (Constant) & .922 & .203 & & & & & \\
\hline & $\begin{array}{l}\text { social } \\
\text { responsibility } \\
\text { towards society }\end{array}$ & .323 & .071 & .340 & 4.581 & .000 & .346 & 2.887 \\
\hline & $\begin{array}{l}\text { social } \\
\text { responsibility } \\
\text { towards } \\
\text { employees }\end{array}$ & .194 & .059 & .254 & 3.282 & .001 & .319 & 3.137 \\
\hline & $\begin{array}{l}\text { social } \\
\text { responsibility } \\
\text { towards } \\
\text { customers }\end{array}$ & .202 & .069 & .222 & 2.952 & .003 & .338 & 2.955 \\
\hline & $\begin{array}{l}\text { social } \\
\text { responsibility } \\
\text { towards } \\
\text { government }\end{array}$ & .006 & .044 & .007 & .136 & .892 & .772 & 1.295 \\
\hline
\end{tabular}

a. Dependent Variable: the emotional commitment 
INTERNATIONAL JOURNAL OF ACADEMIC RESEARCH IN BUSINESS AND SOCIAL SCIENCES Vol. 10, No. 1, Jan, 2020, E-ISSN: 2222-6990 @ 2020 HRMARS

\begin{tabular}{|c|c|c|c|c|c|}
\hline \multicolumn{6}{|c|}{ Model Summary } \\
\hline Model & $\mathrm{R}$ & R Square & $\begin{array}{l}\text { Adjusted R } \\
\text { Square }\end{array}$ & $\begin{array}{c}\text { Std. Error of the } \\
\text { Estimate }\end{array}$ & Durbin-Watson \\
\hline 1 & $.511^{a}$ & .261 & .248 & .44794 & 1.478 \\
\hline
\end{tabular}

a. Predictors: (Constant), (social responsibility towards society - social responsibility towards employees - social responsibility towards customers)

b. Dependent Variable: continuous commitment

\begin{tabular}{|c|c|c|c|c|c|c|c|c|}
\hline & & & Coeff & icients ${ }^{a}$ & & & & \\
\hline & & $\begin{array}{r}\text { Unstanc } \\
\text { Coeffi }\end{array}$ & $\begin{array}{l}\text { lardized } \\
\text { cients }\end{array}$ & $\begin{array}{l}\text { Standardized } \\
\text { Coefficients }\end{array}$ & & & $\begin{array}{r}\text { Colline } \\
\text { Statist }\end{array}$ & \\
\hline & & $\mathrm{B}$ & Std. Error & Beta & $\mathrm{t}$ & Sig. & Toleranœ & VIF \\
\hline 1 & (Constant) & 1.980 & .214 & & 9.232 & .000 & & \\
\hline & $\begin{array}{l}\text { social } \\
\text { responsibility } \\
\text { towards society }\end{array}$ & .220 & .075 & .286 & 2.954 & .003 & .346 & 2.887 \\
\hline & $\begin{array}{l}\text { social } \\
\text { responsibility } \\
\text { towards } \\
\text { employees }\end{array}$ & .101 & .062 & .164 & 1.625 & .105 & .319 & 3.137 \\
\hline & $\begin{array}{l}\text { - social } \\
\text { responsibility } \\
\text { towards } \\
\text { customers }\end{array}$ & .087 & .072 & .118 & 1.202 & .230 & .338 & 2.955 \\
\hline & $\begin{array}{l}\text { social } \\
\text { responsibility } \\
\text { towards } \\
\text { government }\end{array}$ & $-.023-$ & .047 & $-.032-$ & $-.494-$ & .622 & .772 & 1.295 \\
\hline
\end{tabular}

a. Dependent Variable: continuous commitment 
INTERNATIONAL JOURNAL OF ACADEMIC RESEARCH IN BUSINESS AND SOCIAL SCIENCES Vol. 10, No. 1, Jan, 2020, E-ISSN: 2222-6990 @ 2020 HRMARS

\begin{tabular}{|c|c|c|c|c|c|}
\hline \multicolumn{6}{|c|}{ Model Summary } \\
\hline Model & $\mathrm{R}$ & R Square & $\begin{array}{c}\text { Adjusted R } \\
\text { Square }\end{array}$ & $\begin{array}{l}\text { Std. Error of the } \\
\text { Estimate }\end{array}$ & Durbin-Watson \\
\hline 1 & $.513^{\mathrm{a}}$ & .263 & .250 & .39546 & 1.696 \\
\hline
\end{tabular}

a. Predictors: (Constant), (social responsibility towards society - social responsibility towards employees - social responsibility towards customers)

b. Dependent Variable: standard commitment

\begin{tabular}{|c|c|c|c|c|c|c|c|c|}
\hline \multicolumn{9}{|c|}{ Coefficients $^{a}$} \\
\hline \multirow[b]{2}{*}{ Mod } & & \multicolumn{2}{|c|}{$\begin{array}{l}\text { Unstandardized } \\
\text { Coefficients }\end{array}$} & \multirow{2}{*}{$\begin{array}{c}\text { Standardized } \\
\text { Coefficients } \\
\text { Beta } \\
\end{array}$} & \multirow[b]{2}{*}{$t$} & \multirow[b]{2}{*}{ Sig. } & \multicolumn{2}{|c|}{$\begin{array}{c}\text { Collinearity } \\
\text { Statistics }\end{array}$} \\
\hline & & $\mathrm{B}$ & Std. Error & & & & Toleranœ & VIF \\
\hline \multirow[t]{5}{*}{1} & (Constant) & 2.066 & .189 & & 10.915 & .000 & & \\
\hline & $\begin{array}{l}\text { social } \\
\text { responsibility } \\
\text { towards society }\end{array}$ & .224 & .066 & .329 & 3.403 & .001 & .346 & 2.887 \\
\hline & $\begin{array}{l}\text { social } \\
\text { responsibility } \\
\text { towards } \\
\text { employees }\end{array}$ & .163 & .055 & .297 & 2.951 & .004 & .319 & 3.137 \\
\hline & $\begin{array}{l}\text { - social } \\
\text { responsibility } \\
\text { towards } \\
\text { customers }\end{array}$ & $-.086-$ & .064 & $-.131-$ & - & .182 & .338 & 2.955 \\
\hline & $\begin{array}{l}\text { social } \\
\text { responsibility } \\
\text { towards } \\
\text { government }\end{array}$ & .033 & .041 & .052 & .804 & .422 & .772 & 1.295 \\
\hline
\end{tabular}

a. Dependent Variable: standard commitment

\section{Conclusion}

There is a strong direct correlation relationship between the dimensions of social responsibility and emotional commitment, where the multiple correlation coefficient reached (0.75), the model was significant where (sig- $\mathrm{F}<0.05)$, and the value of the modified limiting factor $(55.9 \%)$ representing the relative contribution of the dimensions of social responsibility ( Social responsibility towards society - social responsibility towards workers - social responsibility to customers) in explaining the variance in the level of emotional commitment, and the rest is due to other factors outside the regression patterns in the current study Thus we accept the partially tested hypothes

There is a significant effect of the dimensions of social responsibility (social responsibility towards society - social responsibility towards workers - social responsibility to customers) on the emotional commitment of workers in the private sector of the city of Damascus. 
There is a strong direct correlation relationship between the dimensions of social responsibility and the normative commitment where the multiple correlation coefficient reached (0.507), and the model was significant where $($ sig- $F<0.05)$, and the value of the modified limiting factor $(25 \%)$ representing the relative contribution of the dimensions of social responsibility ( Social responsibility towards society - social responsibility towards workers) in the explanation of variance with the level of normative commitment, and the rest is due to other factors outside the regression model in the current study Thus we accept the partially tested hypothesis There is a significant effect of the dimensions of social responsibility (social responsibility towards society-social responsibility towards workers) on the normative commitment of workers in the private telecommunications sector in Damascus There is a strong direct correlation relationship between the dimensions of social responsibility and continuous commitment where the multiple correlation coefficient reached (0.506), and the model was significant where (sig- $\mathrm{F}<0.05)$, and the value of the modified limiting factor (25\%) representing the relative contribution of the dimensions of social responsibility ( Social responsibility towards society and social responsibility towards workers) in the interpretation of variance with the level of continuous commitment, and the rest is due to other factors outside the regression model in the current study

There is a strong direct correlation relationship between the dimensions of social responsibility and continuous commitment where the multiple correlation coefficient reached (0.506), and the model was significant where (sig- $\mathrm{F}<0.05)$, and the value of the modified limiting factor $(25 \%)$ representing the relative contribution of the dimensions of social responsibility ( Social responsibility towards society and social responsibility towards workers) in the interpretation of variance with the level of continuous commitment, and the rest is due to other factors outside the regression model in the current study

Commenting on the above results, the researcher explains this result to the fact that workers in the communications sector show a feeling that they are part of the organization, which reflects a tremendous impact on their performance and organizational performance, and therefore high levels of employee emotional or emotional commitment do not affect only the continued commitment, and But she also encourages the employee to try to bring other individuals into the organization's talent pool. Where the employee with a high emotional and emotional commitment is considered as the brand's ambassador for the organization and the researcher suggests several reasons for these high rates of emotional commitment among workers, including:

The employee's emotional commitment is directly proportional to the positive work experience and experience. Therefore, it is the policies and strategies that make assessments of appropriate strengths and weaknesses for employees, and create workflow situations and processes in which the largest number of employees individually experience a positive work experience, And it helps build a successful organization.

The focus and great attention that is given by appointing managers who are appropriate for the organization and its members is also to ensure a high level of emotional and emotional commitment in the staff. The emotional commitment is higher when the gap between individual and organizational values is minimal

The researcher explains these results to the fact that workers in the private communications sector are reinforced with a moral sense of adherence to work and have higher levels of normative 
commitment based on a sense of duties and values. The sense of moral obligation and the value system of the individual. And it must be the result of the emotional commitment that has proven its existence in the previous hypothesis, and socialization also has an impact that is reflected within the workplace and the commitment of co-workers.

This is the researcher's opinion that when the ongoing commitment is not fully paid by the emotional commitment, it is usually reflected in the costs that the employee is associated with leaving the organization.

Consequently, the researcher explains that there is a relationship between the dimensions of social responsibility towards the society and towards the workers and the continuous commitment to the compatibility of interests between both society and workers and between the organization.

Undoubtedly, the continuous commitment has proven its existence between each of the two dimensions of responsibility (workers and society), after we have established a relationship between the same two dimensions and the emotional commitment in the first place, followed by the normative commitment. The opposite of both emotional and normative commitment. After a commitment based on love and belonging, and an obligation based on duties and values, it must provide the interests of all parties and is an ongoing commitment.

\section{Theoretical Implications}

This study has many theoretical implications. First, previous research has devoted attention to the mechanism of performing social responsibility (2009 Turker). The current study broadens the focus of CSR research and provides a more sophisticated plan on how the dimensions of social responsibility affect an increased level of organizational commitment (Brammer, Millington \& Rayton, 2007) This paper does not only address the call to consider further models of the relationship between social responsibility and organizational commitment, But also advocate for more empirical research that highlights the importance of dimensions of social responsibility and the strengthening of types of organizational commitment.

Moreover, our results provide evidence for the idea that the survival and success of an organization depend on the organizational commitment of its employees. Finally, this paper demonstrates through studies the strong relationship between social responsibility and organizational commitment.

\section{Practical Outcomes}

Our results also have many practical implications. First, our results point to the importance of social responsibility in its dimensions: responsibility to society. And towards employees with an emotional commitment in the telecommunications sector in Damascus. There is also a relationship between the dimensions of social responsibility towards society and employees with continuous commitment, and it has proven a strong relationship towards society and towards workers in the standard commitment in the telecommunications sector in the city of Damascus.

\section{Directions for Future Research}

Future research trends This study shows that there is a direct relationship between social responsibility and organizational commitment without studying the effects of some modified and 
INTERNATIONAL JOURNAL OF ACADEMIC RESEARCH IN BUSINESS AND SOCIAL SCIENCES

Vol. 10, No. 1, Jan, 2020, E-ISSN: 2222-6990 @ 2020 HRMARS

intermediate variables on this relationship, such as organizational integration and job satisfaction. The effects of environmental factors on the variables must be studied, so we suggest that researchers research how environmental variables to affect the application of the dimensions of social responsibility and its impact on organizational commitment

\section{References}

Acquier, A., Gond, J. P., \& Pasquero, J. (2011). Rediscovering Howard R. Bowen's legacy: The unachieved agenda and continuing relevance of social responsibilities of the businessman. Business \& Society, 50(4), 607-646.

Ahmed, S. U., Islam, Z., Mahtab, H., \& Hasan, I. (2014). Institutional investment and corporate social performance: linkage towards sustainable development. Corporate Social Responsibility and Environmental Management, 21(1), 1-13.

Albrecht, K. (2003). The power of minds at work: Organizational intelligence in action. Amacom Books.

Almeida-Lopes, L., Rigau, J., Amaro Zângaro, R., Guidugli-Neto, J., \& Jaeger, M. M. (2001). Comparison of the low level laser therapy effects on cultured human gingival fibroblasts proliferation using different irradiance and same fluence. Lasers in Surgery and Medicine: The Official Journal of the American Society for Laser Medicine and Surgery, 29(2), 179-184.

Anderson, L. (1997). Argyris and Schön's theory on congruence and learning. Resource papers in Action Research, en www. uq. net. au.

Bagherzadeh, M., \& Akbari, D. A. (2010). Relationship between intelligence and organizational agility.

Bakhshian, A., Hamidi, F., \& Ezati, M. (2011). Relationship between organizational intelligence and entrepreneurship among university educational managers. J Math Comput Sci, 3(4), 413-21.

Breu, K., Hemingway, C. J., Strathern, M., \& Bridger, D. (2002). Workforce agility: the new employee strategy for the knowledge economy. Journal of Information technology, 17(1), 21-31.

Cakir, R., \& Ada, S. (2008). Can the organizational intelligence be developed in schools by in-service training. World Applied Sciences Journal, 4(1), 24-30.

Caught, K., Shadur, M. A., \& Rodwell, J. J. (2000). The measurement artifact in the organizational commitment questionnaire. Psychological Reports, 87(3), 777-788.

Chaman, K., Hesam, S., \& Yazdanpanah, A. (2016). Relationship between organizational intelligence and hospitals agility of shiraz university of medical sciences.

Cronin, B., \& Davenport, E. (1991). Elements of information management. Scarecrow Pr.

Daft, R. L., \& Weick, K. E. (1984). Toward a model of organizations as interpretation systems. Academy of management review, 9(2), 284-295.

Davoudi, A. H. M., Gilandeh, B. G., \& Akbari, A. The Relationship between Organizational Learning and Organizational Intelligence, and Empowerment from Teachers' point of view.

Dutton, J. E., \& Duncan, R. B. (1987). The creation of momentum for change through the process of strategic issue diagnosis. Strategic management journal, 8(3), 279-295.

Dutton, J. E., \& Duncan, R. B. (1987). The creation of momentum for change through the process of strategic issue diagnosis. Strategic management journal, 8(3), 279-295.

Eisenhardt, K. M., \& Martin, J. A. (2000). Dynamic capabilities: what are they?. Strategic management journal, 21(10-11), 1105-1121. 
Ejike, S. I. (2018). An Assessment of Non-Executive Directors Influence on the Operating Profits of Manufacturing Firms in Nigeria, International Journal of Academic Research in Accounting, Finance and Management Sciences 8 (2): 1-8.

El Sawy, O. A. (1985). Personal information systems for strategic scanning in turbulent environments: can the CEO go on-line?. MiS Quarterly, 53-60.

Erande, A. S., \& Verma, A. K. (2008). Measuring agility of organizations-a comprehensive agility measurement tool (CAMT). International journal of applied management and technology, $6(3)$.

Florin, L. E. O. N., \& Atanasiu, G. M. (2008). Integrating artificial intelligence into organizational intelligence. Management \& Marketing, 3(2).

Glynn, M. A. (1996). Innovative genius: A framework for relating individual and organizational intelligences to innovation. Academy of management review, 21(4), 1081-1111.

Gunasekaran, A. (1999). Agile manufacturing: a framework for research and development. International journal of production economics, 62(1-2), 87-105.

Halal, W. E. (2002). Organizational intelligence: a broader framework for understanding knowledge. On the Horizon, 10(4).

Houghton, R., El Sawy, O. A., Gray, P., Donegan, C., \& Joshi, A. (2008). Vigilant information systems for managing enterprises in dynamic supply chains: Real-time dashboards at Western Digital. MIS Quarterly Executive, 3(1), 4.

Khodadadi, M. R., Kashef, M., Seyed Ameri, M., \& Aalami Kashki, M. (2013). The relationship between the components of organizational intelligence and organizational culture in the general department of exercise of east Azerbayjan. Exercise Management, 5(3), 175-189.

Kord, B., Ghasemi, M., \& Khazaei Amin, A. (2013). Measuring the organizational intelligence of the experts and managers of the cement factory in Sistan. European Online Journal of Natural and Social Sciences: Proceedings, 2(3 (s)), pp-959.

Kotler, P., \& Lee, N. (2005). Best of breed: When it comes to gaining a market edge while supporting a social cause, "corporate social marketing" leads the pack. Social marketing quarterly, 11(34), 91-103.

Lefter, V., Prejmerean, M., \& Vasilache, S. (2008). The dimensions of organizational intelligence in Romanian companies-a human capital perspective. Theoretical and Applied Economics, 10(10), 39.

Liebowitz, J. (2019). Building organizational intelligence: A knowledge management primer. CRC press.

Loforte Ribeiro, F., \& Timóteo Fernandes, M. (2010). Exploring agile methods in construction small and medium enterprises: a case study. Journal of Enterprise Information Management, 23(2), 161-180.

Mathieu, J. E., \& Zajac, D. M. (1990). A review and meta-analysis of the antecedents, correlates, and consequences of organizational commitment. Psychological bulletin, 108(2), 171.

Matsuda, T. (1988). OR/MS, its interaction with and benefit from Japanese organizational intelligence. Omega, 16(3), 233-241.

McCann, J., Selsky, J., \& Lee, J. (2009). Building agility, resilience and performance in turbulent environments. People \& Strategy, 32(3), 44-51. 
INTERNATIONAL JOURNAL OF ACADEMIC RESEARCH IN BUSINESS AND SOCIAL SCIENCES

Vol. 10, No. 1, Jan, 2020, E-ISSN: 2222-6990 @ 2020 HRMARS

McCarthy, I. P., Lawrence, T. B., Wixted, B., \& Gordon, B. R. (2010). A multidimensional conceptualization of environmental velocity. Academy of management review, 35(4), 604626.

McMaster, M. D. (1996). The intelligence advantage: Organizing for complexity. Boston: ButterworthHeinemann.

Orlitzky, M., Schmidt, F. L., \& Rynes, S. L. (2003). Corporate social and financial performance: A metaanalysis. Organization studies, 24(3), 403-441.

Park, Y. K. (2011). The Dynamics of Opportunity and Threat Management in Turbulent Environments: The Role of Information Technologies. ProQuest LLC. 789 East Eisenhower Parkway, PO Box 1346, Ann Arbor, MI 48106.

Peterson, C., \& Seligman, M. E. (2004). Character strengths and virtues: A handbook and classification (Vol. 1). Oxford University Press.

Prater, E., Biehl, M., \& Smith, M. A. (2001). International supply chain agility-Tradeoffs between flexibility and uncertainty. International journal of operations \& production management, 21(5/6), 823-839.

Ramesh, G., \& Devadasan, S. R. (2007). Literature review on the agile manufacturing criteria. Journal of Manufacturing Technology Management, 18(2), 182-201.

Rasouli, E., Soodi, S., \& Jafarzadeh, Z. (2016). Studying the relationship between organizational intelligence and organizational agility of employees of Payame Noor University of Sari. International Journal of Organizational Leadership, 5, 426-432.

Rasouli, E., Soodi, S., \& Jafarzadeh, Z. (2016). Studying the relationship between organizational intelligence and organizational agility of employees of Payame Noor University of Sari. International Journal of Organizational Leadership, 5, 426-432.

Ruhan, A., lijima, J., \& Sho, H. (2009). A study on relationship between organizational intelligence quotient and firm performance-A comparison study between Japan and China. Tokyo Institute of Technology.

Sahid, N. Z., Noordin, S. A., \& Sani, M. K. J. A. (2018). Customer-Driven Business Information provision in Malaysian Government Agencies' Library. International Journal of Academic Research in Progressive Education and Development, 7(3), 137-149.

Sattari, M. (2007). The relationship between knowledge maangement in learining organization and emotional intelligence in Zoube Ahan Efahana Company. First Conferenceon Knowledge Management, Tehran, Iran.

Schwaninger, M. (2006). Intelligent organizations: Powerful models for systemic management. Springer Science \& Business Media.

Smircich, L., \& Stubbart, C. (1985). Strategic management in an enacted world. Academy of management Review, 10(4), 724-736.

Thomas, J. B., Clark, S. M., \& Gioia, D. A. (1993). Strategic sensemaking and organizational performance: Linkages among scanning, interpretation, action, and outcomes. Academy of Management journal, 36(2), 239-270.

Todd, S. (2007). Feminist community organizing: The spectre of the sacred and the secular. J. Coates, JR Graham, \& B. Swartzentruber, with B. Ouellette (Eds.), Spirituality and social work: Selected Canadian readings, 161-174. 
INTERNATIONAL JOURNAL OF ACADEMIC RESEARCH IN BUSINESS AND SOCIAL SCIENCES

Vol. 10, No. 1, Jan, 2020, E-ISSN: 2222-6990 @ 2020 HRMARS

Turker, D. (2009). How corporate social responsibility influences organizational commitment. Journal of Business ethics, 89(2), 189.

Wassermann, O. (2001). The intelligent organization: Winning the global competition with the supply chain idea. Springer Science \& Business Media.

Wilensky, H. L. (2015). Organizational intelligence: Knowledge and policy in government and industry (Vol. 19). Quid Pro Books.

Yusuf, Y. Y., Sarhadi, M., \& Gunasekaran, A. (1999). Agile manufacturing:: The drivers, concepts and attributes. International Journal of production economics, 62(1-2), 33-43. 